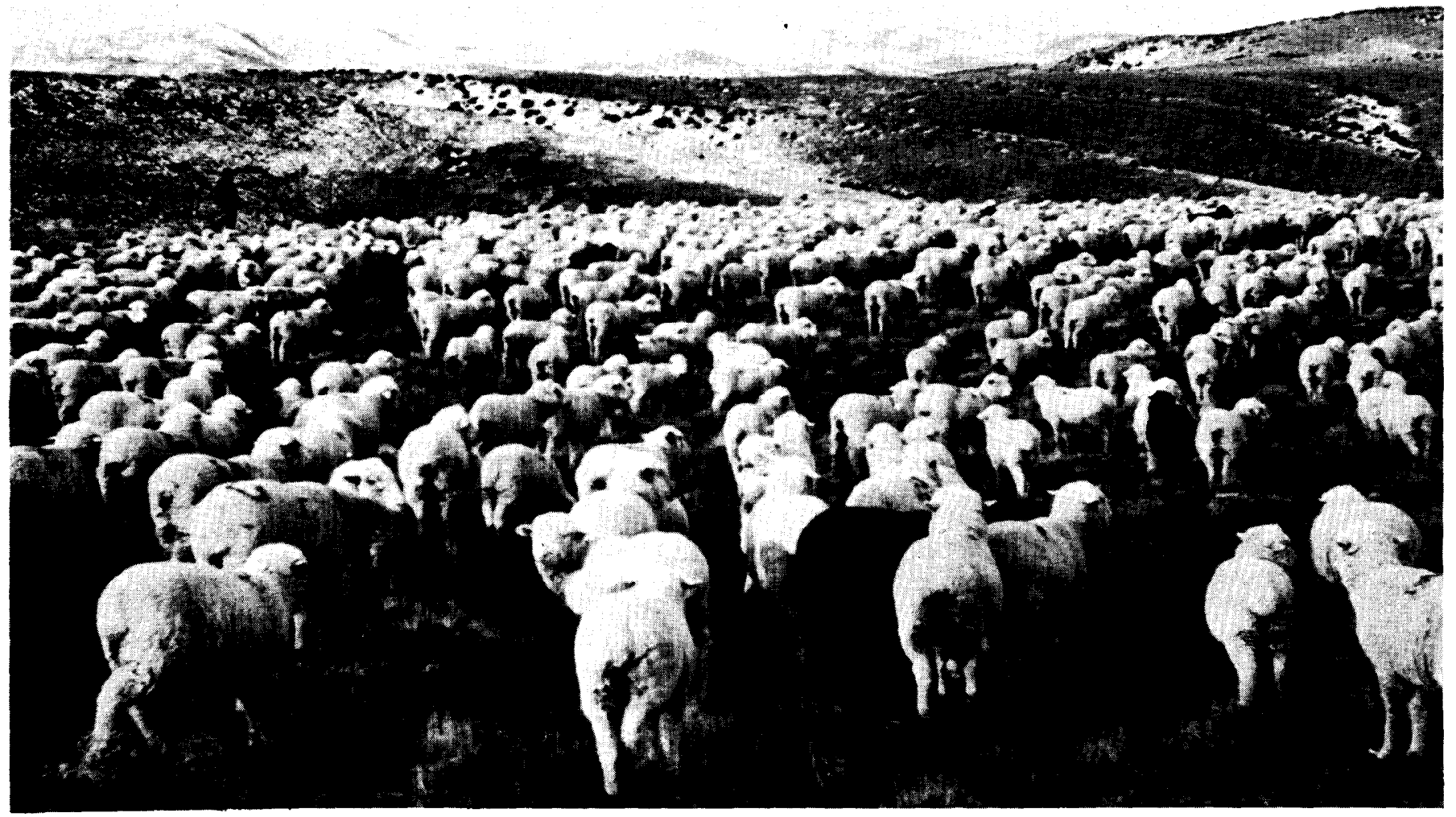

\title{
Predation on Domestic Sheep in Northeastern Nevada
}

\section{DONALD A. KLEBENOW AND KENT MCADOO}

Highlight: $A$ northern Nevada range band of sheep was studied in order to verify the extent of losses to predation and to other causes. Daily searches were made for losses and carcasses were autopsied. During lambing, predator losses varied on the two operations studied, 1 loss per 14 days in one case and 1 loss per day in the other. Losses from other causes were high at that time. Predation increased in late summer and continued to be high into the fall. Predation was the major cause of loss at that time. Winter losses were variable. In one short period, 38 head of sheep were lost to halogeton (Halogeton glomeratus). In one annual production cycle $9 \%$ of the band was the total verified loss. The verified predator loss was $4 \%$ of the band. The coyote (Canis latrans) accounted for $91 \%$ of the total predation.

A Society for Range Management (1971) statement on predator control noted that although range sheep operations undoubtedly suffer economic loss from predation, "there is no hard evidence to substantiate the actual loss or how it may fluctuate through time or from area to area." Cain et al. (1972) recommended that field studies are needed to "determine with all possible accuracy the actual livestock losses caused by each major predator," as well as those losses due to other causes.

Authors are associate professor and graduate fellow, Division of Renewable Natural Resources, University of Nevada, Reno.

Manuscript received October $14,1975$.
Our research was a field study to determine the extent of loss due to predators in relation to total loss suffered by a typical Nevada sheep band.

This study covered the annual production cycle for one band of sheep from lambing on May 5, 1973, through the end of spring trail on April 20,1974, plus an additional lambing period with a band from another rancher.

\section{Study Areas}

The sheep chosen for initial study were owned and managed by Jess and Elias Goicoechea. They were a band herded on rangelands for the entire year. Lambing occurred in Elko County. The area was between 6,200 and $7,000 \mathrm{ft}$ in elevation, and comprised primarily of northern desert shrub type vegetation, with scattered wet meadows near springs (Fig. 1a). The dominant shrubs were big sagebrush (Artemisia tridentata), often as much as $6 \mathrm{ft}$ high, and low sagebrush (Artemisia arbuscula). The principal grasses were primarily bluegrass (Poa spp.) and cheatgrass brome (Bromus tectorum).

Summer range was in northern Elko County. Elevation ranged between 6,500 and $8,800 \mathrm{ft}$, and the area was dominated by mountain brush and northern desert shrub type vegetation (Fig. $1 \mathrm{~b}$ and $1 \mathrm{c}$ ). Big sagebrush, bitterbrush (Purshia tridentata), and snowberry (Symphoricarpos spp.) were the common shrubs in the area. Grasses and forbs included bluebunch wheatgrass (Agropyron spicatum), cheatgrass brome, bluegrass, arrowleaf balsamroot (Balsamorhiza sagittata), and Indian paintbrush (Castilleja spp.). In addition, 
groves of willow (Salix spp.) and aspen (Populus tremuloides) were common along stream bottoms. Small stands of white fir (Abies concolor) and aspen occurred at higher elevations, particularly on concave north slopes.

The sheep were trailed from summer ranges to winter ranges in White Pine and northeastern Nye counties. Winter ranges were located on valley floors, about 6,000 ft elevation, composed primarily of northern desert shrub and salt desert shrub type vegetation (Fig. 1d). Big sagebrush, low sagebrush, rabbitbrush (Chrysothamnus spp.), cheatgrass, and other grasses were common in the area. Shadscale (Atriplex confertifolia), and winterfat (Eurotia lanata) occurred in alkaline flats. Halogeton (Halogeton glomeratus) also occurred on much of the winter range. On those allotments which bordered foothills, Utah juniper (Juniperus osteosperma) was common.

During the 1974 lambing season, the study band was one owned by Paris Brothers Livestock Company, located in Butte Valley, White Pine County, Nev. The elevation and vegetation was similar to the winter ranges occupied by the Goicoechea operation (Fig. 1d). Rabbitbrush and stands of winterfat were common on the valley floor.

\section{Methods}

At lambing, each band was similar in size, 1,113 ewes in the
Goicoechea band and 1,134 in the one owned by Paris Brothers. At docking and through the remainder of the year the number of sheep in the Goicoechea band, including lambs, ranged from 2,466 at docking down to 2,221 on the spring trail. Reorganization of the band occurred several times during the year resulting in some variation in band size. The average size was 2,405 sheep.

The sheep were checked daily throughout the year. An investigator accompanied the herder each morning as the sheep were being moved off bedding areas. The bedding grounds and surrounding vicinities were checked thoroughly for losses afoot or on horseback, and by glassing all open areas. Dogs were used occasionally.

Strays, sheep that were wounded, crippled, diseased or otherwise incapacitated and left back, were located by making trips into areas previously occupied or trailed through by the sheep. The periphery of the band was checked daily for sick, slower-moving animals.

When a carcass was located, the cause of death was verified when possible. The objective was to differentiate between predator losses, death losses due to causes other than predation, carrion feeding, and sheep losses where death had not yet occurred. The techniques for verifying cause of death have been described by Rowley (1969, 1970), Wiley and Bolen (1971), and Bowns et al. (1973).

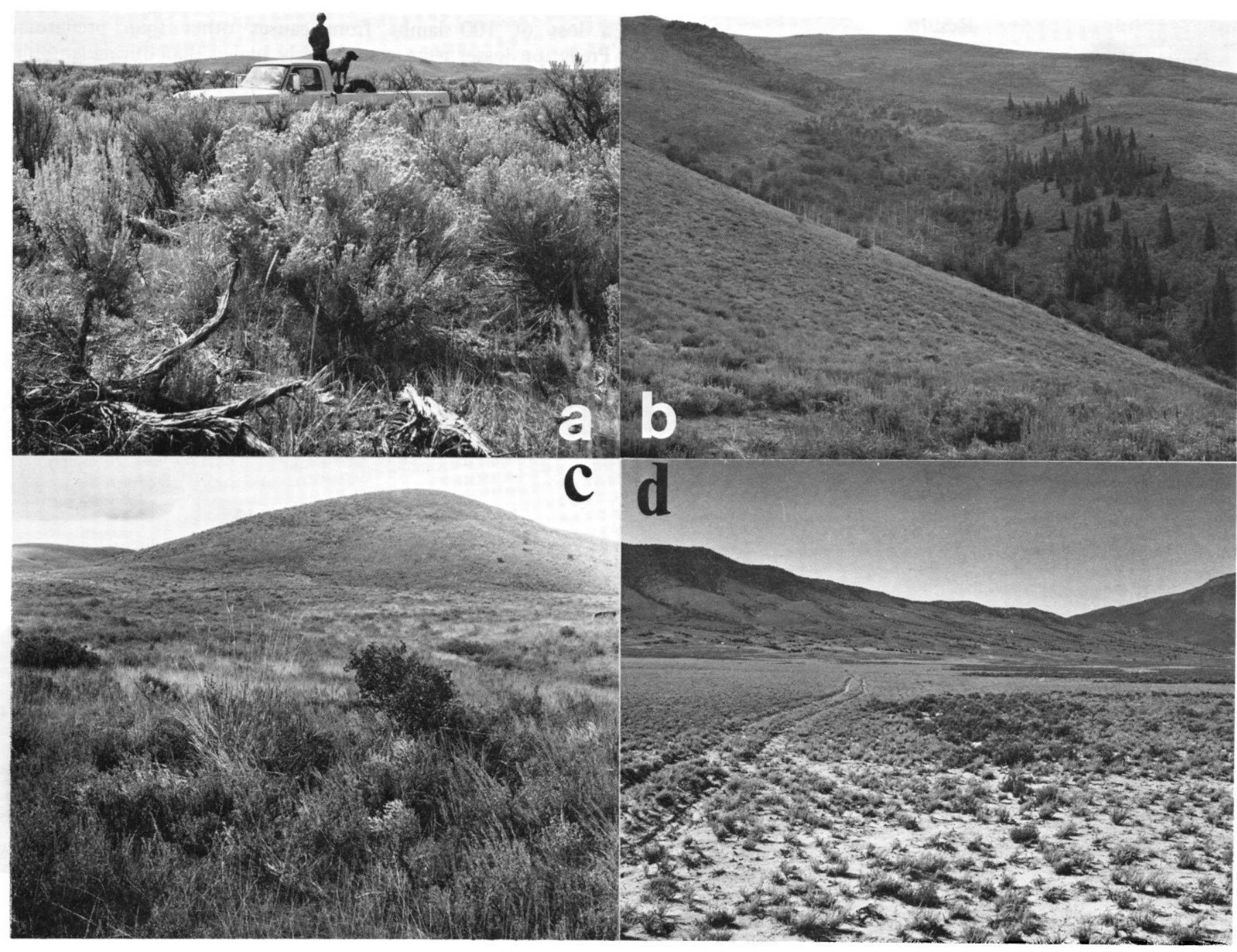

Fig. 1. Study areas in Elko and White Pine counties, Nevada: (a) Big sagebrush on lambing range; (b) Summer range with white fir, aspen, snowberry, and big sagebrush; (c) Summer range dominated by big sagebrush, antelope bitterbrush, bluebunch wheatgrass with scattered serviceberry; (d) Valley floors where winterfat and big sagebrush were interspersed provided winter range. 
Counts of the number of sheep in the band permitted a comparison between verified and actual losses. The six counts made of the Goicoechea band during the year were made when ranch management permitted or required a census. No counts were made of ewes and new-born lambs at the beginning of either lambing season. Typically, the count at docking is the first one in a range-lambing operation.

The predator species involved in each attack were identified by wounds and types of consumption damage. Other aids were evidence at kill site, such as tracks and droppings, and observations of predators in the area. Major references on predator identification include Rosko (1948), Gier (1957), Rowley (1970), Wiley and Bolen (1971), and Bowns et al. (1973).

To determine the physical condition of predator losses, victims were examined for any external abnormalities (swollen joints, broken bones, general emaciation, etc.). Lacking any external evidences of a weak condition, a lamb was judged to be either healthy or unhealthy by its relative size compared to the other lambs at that time.

For purposes of this study, sheep were divided into two age classes:

1. lambs-sheep under 12 months old (all sheep born during the study).

2. ewes (adults)-all sheep more than one year old.

\section{Results}

During the early part of the study, from the beginning of the lambing period until the sheep arrived on their summer range, predation was low (Table 1). During those periods, losses related to the birth of lambs were common. There were stillborn lambs, orphaned and abandoned lambs, and ewes lost to birth complications. Others died of diseases or from poisonous plants. Accidental deaths were caused by faulty castration, drowning, and trampling in corrals. Just three lambs were verified losses to predators, a loss of one lamb per 14 days.

Following arrival on the summer range, predation intensity increased and predators were the major cause of losses. A high intensity of predation, one loss per day, was reached in late summer and the intensity remained high until shipping time was reached in mid-October. Fifty-five sheep were lost to predators during that late summer and fall period and 53 were lambs. Following shipping, the intensity of predation dropped and continued to drop through mid-winter. Only one lamb was killed during the 42-day mid-winter period. Then the rate increased, and during the 12-day period on the spring trail, five sheep were lost to predators. The Goicoechea band incurred an average predation intensity of one loss every 4 days during the complete production cycle. Ninety-two percent of all the Goicoechea predator losses were lambs.

Losses other than predation were particularly high during the mid-winter period. Of the 46 losses that occurred, 38 were sheep killed during a 3-day period in February from poisoning by halogeton.

The Paris band, studied the second lambing season, suffered a loss of 100 lambs from causes other than predators. Predation losses were considerably higher than during lambing on the Goicoechea range the year before. Twenty-five losses were verified for a predator intensity of one loss per day.

When actual losses based on census were compared with the verified losses (Table 2), we found we could explain 180 of

Table 1. Domestic sheep losses and predation intensity verified from one Nevada range band during the 1973-74 production cycle and from another band during lambing, 1974.

\begin{tabular}{|c|c|c|c|c|c|c|c|c|c|}
\hline \multirow[b]{3}{*}{ Time period } & \multirow{3}{*}{$\begin{array}{l}\text { Length } \\
\text { of period } \\
\text { (days) }\end{array}$} & \multicolumn{7}{|c|}{ Verified losses } & \\
\hline & & \multicolumn{2}{|c|}{ Predation } & \multicolumn{2}{|c|}{ Other } & \multicolumn{2}{|c|}{ Total } & \multirow{2}{*}{\multicolumn{2}{|c|}{$\begin{array}{c}\text { Predation } \\
\text { in tensity } \\
(1 \text { loss/no. } \\
\text { days })\end{array}$}} \\
\hline & & Ewes & Lambs & Ewes & Lambs & Predation & Other & & \\
\hline \multicolumn{10}{|l|}{$\begin{array}{l}\text { Goicoechea band } \\
\text { Lambing }\end{array}$} \\
\hline $\begin{array}{l}\text { Trail to summer } \\
\text { range }\end{array}$ & 72 & & J & $1 \mathrm{~J}$ & 22 & J & (I & $1 / 14$ & \\
\hline $6 / 16-6 / 30 / 73$ & 15 & - & - & - & 12 & - & 12 & - & \\
\hline $\begin{array}{l}\text { Early summer } \\
7 / 1-8 / 15 / 73\end{array}$ & 46 & - & 11 & 1 & 7 & 11 & 8 & $1 / 4$ & \\
\hline $\begin{array}{l}\text { Late summer } \\
8 / 16-9 / 15 / 73\end{array}$ & 31 & - & 35 & 2 & 5 & 35 & 7 & $1 / 1$ & \\
\hline $\begin{array}{l}\text { Trail to shipping } \\
9 / 16-10 / 12 / 73\end{array}$ & 27 & 2 & 18 & - & 5 & 20 & 5 & $1 / 1$ & \\
\hline $\begin{array}{l}\text { Fall trail } \\
10 / 13-11 / 28 / 73\end{array}$ & 47 & - & 5 & 2 & 1 & 5 & 3 & $1 / 9$ & \\
\hline $\begin{array}{l}\text { Early winter } \\
11 / 29 / 73-1 / 17 / 74\end{array}$ & 50 & 1 & 4 & 4 & 1 & 5 & 5 & $1 / 10$ & \\
\hline $\begin{array}{l}\text { Mid-win ter } \\
1 / 18-2 / 28 / 74\end{array}$ & 42 & - & 1 & 24 & 22 & 1 & 46 & $1 / 42$ & 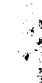 \\
\hline $\begin{array}{l}\text { Late winter } \\
3 / 1-4 / 8 / 74\end{array}$ & 39 & 4 & 7 & 4 & 2 & 11 & 6 & $1 / 4$ & 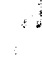 \\
\hline $\begin{array}{l}\text { Spring trail } \\
4 / 9-4 / 20 / 74\end{array}$ & 12 & 1 & 4 & - & 1 & 5 & 1 & $1 / 2$ & \\
\hline $\begin{array}{l}\text { Total period } \\
5 / 5 / 73-4 / 20 / 74\end{array}$ & 351 & 8 & 88 & 52 & 78 & 96 & 130 & & \\
\hline $\begin{array}{l}\text { Paris band } \\
\text { Lambing } \\
5 / 1-5 / 25 / 74\end{array}$ & 25 & 0 & 25 & 12 & 88 & 25 & 100 & $1 / 1$ & \\
\hline
\end{tabular}


Table 2. Verification success and percent predation losses from a range band of sheep during one annual production cycle.

\begin{tabular}{lcc}
\hline \multicolumn{1}{c}{ Measurement } & \multicolumn{3}{c}{$\begin{array}{c}\text { Percent } \\
\text { Number of band }\end{array}$} \\
\hline $\begin{array}{l}\text { Actual losses based on census 6/15/73-4/8/74 } \\
\text { Verified losses during period covered by census }\end{array}$ & 210 & 9 \\
$6 / 15 / 73-4 / 8 / 74$ & 180 & 7 \\
$\begin{array}{l}\text { Total verified losses- lambing 5/5/73-end of } \\
\text { spring trail 4/20/74 }\end{array}$ & 226 & 9 \\
Predator losses verified 5/5/73-4/20/74 & 96 & 4 \\
\hline
\end{tabular}

210 losses or $86 \%$ of the losses that occurred. The period covered by census did not include the entire production cycle. The sheep were not censused prior to lambing, the number of lambs born were not counted at birth, and the sheep were not counted at the end of the spring trail. The total verified losses for the entire production period were $226,9 \%$ of the band. Predator losses for the entire production cycle totaled 96. Four percent of the band was the verified loss to predators.

Coyotes were the major predator (Table 3). The losses caused by dog, bobcat, and golden eagle were insignificant in comparison. No instances of predation by mountain lion were verified.

The physical condition of $81 \%$ of all predator losses was good when attacked (Table 4). Seven sheep were in poor condition. Three were orphaned lambs observed during lambing season, three were small lambs at tacked during the summer period and one was an old, sick, ewc left back as the sheep were moved off a bedding area in March. Physical condition was considered nonassessable for 16 hseep. These animals had been consumed to such a degree by predators and/or scavengers that accurate assessment was impossible.

\section{Discussion}

It was virtually impossible to census the number of lambs born under open-range lambing conditions. In the Goicoechea operation the study band of ewes at lambing was scattered throughout an area approaching 6 square miles in size. The vegetation prevented close observation (Fig. 1a). Therefore, the number of actual losses between the start of lambing and until docking could not be determined. The 25 verified lamb losses for the Goicoechea band prior to docking (Table 1) were probably a relatively small percentage of actual losses incurred during this period.

Venkatachalam et al. (1949) and Safford and Hoversland (1960) reported that lamb mortality during the first few weeks after birth represents a considerable loss to sheepmen. Rambouillets (the basic breed of sheep in the Goicoechea and Paris bands) showed an average lamb loss of $15 \%$ to 120 days

Table 3. The type of predators preying on domestic sheep during the entire production cycle of one band, plus the lambing period of another.

\begin{tabular}{lcc}
\hline & \multicolumn{2}{c}{ Losses } \\
\cline { 2 - 3 } Predator & Number & $\begin{array}{c}\text { Percent } \\
\text { of total }\end{array}$ \\
\hline Coyote & 110 & 91 \\
Dog & 2 & 2 \\
Bobcat & 3 & 2 \\
Golden eagle & 1 & 1 \\
Undetermined & 5 & 4 \\
\hline
\end{tabular}

of age in an Illinois study (Vetter et al., 1960). Early et al. (1974a and b) reported more lamb deaths occurred during the lambing period than during any other time, despite this being the shortest time interval. In his study, $36 \%$ of the total lamb deaths were found to occur during the lambing period. The accuracy of our data during the lambing periods is speculative and we consider our results to be only a minimal estimate of losses during that time. This is true even during the second lambing period with the Paris band when more losses were discovered. During that time, the vegetation permitted more visibility on the lambing grounds (Fig. 1d), the ewes were more closely herded and not scattered as widely as the year before, and project personnel had more experience in locating losses. Still we are certain losses occurred that were not verified. A coyote den with at least three pups was discovercd on the lambing grounds. A lamb's ear within 5 yards of the den was all that remained of a lamb that had been carried off and nearly all consumed. We suspect others were fully consumed by coyotes.

Predators accounted for $22 \%$ of the total verified losses in Paris' band during lambing compared with $12 \%$ for the Goicoechea band during lambing. Therefore, relative to other losses during lambing, predator losses appear to have been more significant for the Paris band than for the Goicoechea band. Predator losses were very much exceeded by natural losses among new-born lambs in both operations.

During summer, predation was a major cause of losses. During the early and late summer periods, $75 \%$ of our verified losses were due to predation. In a Utah study, $74 \%$ of total summer losses were verified as predator caused (Bowns et al., 1973). Apparently, natural losses are typically lower during this time of year.

In late summer, during a 31-day period, a loss of 35 lambs was verified. Apparently this critical period occurs annually. Rosko (1948) verified more losses in August than during either June or July for sheep in Utah, and he noted that losses remained high until mid-September. A similar late summer increase in predation on sheep occurred in Saskatchewan, Canada. ${ }^{1}$ The increased predation during late summer in the study area was forecast by the government trapper, herders, and the operator.

As the Goicoechea sheep were trailed from summer range to winter range, the occurrence of predator losses became less frequent. A similar pattern has been reported for Utah herds in general (Bowns et al., 1973).

Between docking and the end of the production cycle of the Goicoechea band, eight predator losses and four other losses were reported by the herder but not verified by us. These instances in which verification did not occur were due largely to one or morc of the following circumstances: (1) heavy cover in the vicinity of a reported loss; (2) inclement weather (particularly heavy fog); or (3) trailing conditions (no time to drop back for verification). In no instance did the herder ever report on a loss to predation that was later verified to be due to other causes, or vice versa. These additional losses were probably truthful, but were not included in Table 1. Incidentally, were it not for our study, we estimate the herders would have discovered only a third to one-half of the losses that occurred. The attention that the living sheep require does not permit time for a herder to account for dead animals.

'Personal communication with T. Rock, Wildlife Branch, Department of Natural Resources, Saskatoon, Sask. 
The predator losses we verified, $4 \%$ (Table 2), fall within the range reported by several studies. Herd loss to predators based on rancher surveys reported from 3\% in Utah during 1968-1969 (Nielson and Curle, 1970), to $3.4 \%$ in Idaho during both 1970-1971 (Early et al., 1974a) and 1972-1973 (Early et al., 1974b), and from 3.6 to $7.9 \%$ in various years between 1966-1969 for four western states (Reynolds and Gustad, 1971). According to the Morris estimates, as reported hy Cain et al. (1972), losses in Utah between the late 1940's and 1965 ranged from 2 to $4 \%$ in most years.

Presnall (1948) estimated losses of 1.5 to $2 \%$ for all the western ranges and Evanson (1967) estimated an annual loss of $1 \%$ of the flocks in the 17 western states. In a California verification/questionnaire study involving seven ranches, Nesse (1973) calculated an annual predation rate of $1.17 \%$ in 1972 , and $0.50 \%$ in 1973 . The loss of $4 \%$ of the Goicoechea band to predators is considerably higher than the predation rates reported in these studies.

During the critical summer season (docking through shipping), $5 \%$ of the Goicoechea lambs counted at docking (and 3\% of the entire band) was lost to predation. Compared to the results of two other verification studies, these percentages seem relatively high. Rosko (1948) reported that Utah herds in his study suffered an average herd loss of $0.29 \%$ during the summer. The highest loss recorded for one herd was $1.75 \%$. In another Utah study (Bowns et al., 1973), the average summer lamb loss to predators for 10 flocks was $1.1 \%$, with one band suffering a $4.1 \%$ loss.

Several studies (Rosko, 1948; Nielson and Curie, 1970; Bowns et al., 1973; Nesse, 1973) have shown that predator losses vary considerably from one operation to another. Variations in predator abundance, natural prey availability, management of sheep, terrain, and intensity of predator control are no doubt largely responsible for the predator loss fluctuations from one herd to another and from one year to the next.

Coyotes were responsible for $91 \%$ of all predator losses verified during this study. Nesse (1973) attributed $97 \%$ of the predator losses in Glenn County, California during the 1973 production period to coyotes. Coyotes were also found to be by far the major predators on domestic sheep in two Idaho studies (Early et al., 1974a and b), and three Utah studies (Rosko, 1948; Nielson and Curle, 1970; Bowns et al., 1973). The statement by Presnall (1948) that coyotes are the major predator on sheep in the West seems well based.

Data collected during this study do not show evidence that predators select for weak, sick, or otherwise physically disabled domestic sheep (Table 4). The reverse may be true for wild ungulates (Cowan, 1974; Crisler, 1956; Mech, 1966). However, domestic species such as sheep are probably much more susceptible to predators due to thousands of years of domestication which has bred out natural defense and/or escape mechanisms (Kupper, 1945; Howard, 1974). There is no logical reason to believe that coyotes are forced to select for unfit individuals among an introduced species which, even when healthy, are susceptible as prey.

\section{Literature Cited}

Bowns, J. E., J. W. Davenport, J. P. Workman, D. B. Nielson, and D. D. Dwyer. 1973. Determination of cause and magnitude of sheep losses in southwestern Utah. Utah Sci. 34:35-37, 52.

Cain, S. A., J. A. Kadlec, D. L. Allen, R. A. Cooley, M. G. Hornocker, A. S. Leopold, and F. H. Wagner. 1972. Predator control-1971. Report to the Council on Environmental Quality and the Department of the Interior by the Advisory Committee on Predator Control. Univ. of Michigan Press, Ann Arbor. 207 p.

Cowan, I. M. 1947. The timber wolf in the Rocky Mountain National Parks of Canada. Canadian J. Res. 25:139-174.

Crisler, L. 1956. Observations of wolves hunting caribou. J. Mammal. 37:337-346.

Early, O. E., J. C. Roetheli, and G. R. Brewer. 1974a. An economic study of predation in the Idaho range sheep industry, 1970-71 production cycle. Idaho Agr. Res. Prog. Rep. No. 182. 49 p.

Early, O. E., J. C. Roetheli, and G. R. Brewer. 1974b. An economic study of predation in the Idaho range sheep industry, 1972-1973. Idaho Agr. Res. Prog. Rep. No. 186.46 p.

Evanson, R. M. 1967. Predator control and the sheep-raising industry. PhD Diss. George Washington Univ. $461 \mathrm{p}$.

Gier, H. T. 1957. Coyotes in Kansas. Kansas State Univ. Agr. Exp. Sta. Bull. $343.97 \mathrm{p}$.

Howard, W. E. 1974. The biology of predator control. Addison-Wesley Publ. Co., Inc. $48 \mathrm{p}$.

Kupper, W. 1945. The golden hoof. Alfred A. Knopf, New York. 343 p.

Mech, L. D. 1966. The wolves of Isle Royale. Nat. Park Serv. Fauna Ser. 7. 210 p.

Nesse, G. E. 1973. Predation and the sheep industry in Glenn County, California. MS Thesis, Univ. of California, Davis. 127 p.

Nielson, D. B., and D. Curle. 1970. Predator costs to Utah's range sheep industry. Nat. Woolgrower 60:14-22.

Presnall, C. C. 1948. Applied ecology of predation on livestock ranges. J. Mammal. 29:155-161.

Reynolds, R. N., and O. C. Gustad. 1971. Analysis of statistical data on shecp losses caused by predation in four western states during 1966-1969. U.S. Bur. Sport Fish. and Wildl., Div. Wildl. Serv. Rep. $21 \mathrm{p}$.

Rosko, L. 1948. Losses of sheep from predatory animals on summer ranges in Iron County, Utah. Utah Coop. Wildl. Res. Unit Rep. 16 p.

Rowley, I. 1969. An evaluation of predation by "crows" on young lambs. Common. Sci. and Ind. Res. Organ., Aust., Wildl. Res. 14:153-179.

Rowley, I. 1970. Lamb predation in Australia: incidence, predisposing conditions, and the identification of wounds. Common. Sci. and Ind. Res. Organ., Aust., Wildl. Res. 15:79-123.

Safford, J. W., and A. S. Hoversland. 1960. A study of lamb mortality in a western range flock. I. Autopsy findings on 1051 lambs. J. Anim. Sci. 19:265-273.

Society for Range Management. 1971. SRM statement on predator control. Rangeman's News $3: 1,3$.

Venkatatchalam, R. H., R. H. Nelson, F. Thorp, R. N. Luecke, and M. L. Gray. 1949. Causes and certain factors affecting lamb mortality. J. Anim. Sci 8:392.

Vetter, R. L., H. W. Norton, and H. S. Garrigus. 1960. A study of preweaning death losses in lambs. J. Anim. Sci. 19:616-619.

Wiley, R. W., and E. G. Bolen. 1971. Eagle-livestock relationships: livestock carcass census and wound characteristics. Southwestern Nat. 16:151-169. 